\title{
Age estimation of abrasion by their colour changes
}

\author{
Divyesh Saxena1, Manish Nigam ${ }^{2, *}$, Pradeep Kumar Mishra ${ }^{3}$, Jitendra Singh Tomar ${ }^{4}$
}

\begin{abstract}
${ }^{1}$ Senior Resident, Dept. of Forensic Medicine \& Toxicology, All India Institute of Medical Sciences, Rishikesh, Uttarakhand ${ }^{2}$ Professor and Head, Dept. of Forensic Medicine \& Toxicology, Government Autonomous Medical College, Vidisha, Madhya Pradesh, ${ }^{3}$ Professor, Dept. of Forensic Medicine \& Toxicology, Government Medical College, Ratlam, Madhya Pradesh,

${ }^{4}$ Assistant Professor, Dept. of Forensic Medicine \& Toxicology, M.G.M. College, Indore, Madhya Pradesh, India
\end{abstract}

\section{*Corresponding Author:}

Email: jurimanish@gmail.com

\begin{abstract}
Estimation of an injury in living as well in dead is of paramount importance in any criminal investigation. Determination of the age of injuries is crucial in clinical forensic medicine work because it is related to the time of occurrence of the crime. Doctor is required to ascertain the date of injuries while preparing an injury report. Present study illustrates the sequential changes in abrasive injuries and to compare the findings with available standard data. All the medico-legal cases brought to the emergency/ OPD/IPD /cases or for post mortem examination were selected over a period of 18 months who were having abrasions on their body. On comparing with standard data, $100 \%$ individual showed bright red abrasion for first $12 \mathrm{hrs}$. Scab formation was completed within 12 to $48 \mathrm{hrs}$ in $7 \%$ individuals and within $24-48 \mathrm{hrs}$ in $93 \%$ individuals. Healing reached another stage of scab turning dark brown on $3^{\text {rd }}$ and $4^{\text {th }}$ day in $41 \%$ individuals while it was seen completed on day 5 in $18 \%$ individual. Observations of this study was similar at times but not regularly often with the sequential colour changes mentioned in the available literature.
\end{abstract}

Keywords: Age, Estimation, Abrasion, Colour.

\section{Introduction}

Each clue or evidence in medicolegal cases are important for investigatory purpose. Injuries may be inflicted in the form of abrasion, contusion or laceration as a result of assault or accident. Severity of these injuries are governed by the type of weapon used or force of impact. Under IPC section 44, the word injury denotes any harm whatever illegally caused to any person, in body, mind, reputation or property. ${ }^{1}$ Abrasion are the injuries that involve superficial layer of the skin, the epidermis or mucous membrane due to impact against blunt and rough weapons. ${ }^{2}$ The most important aspect in clinical forensic medicine work is to determine the age of injuries. All injuries undergo time dependant changes while passing through all stages of healing. Therefore so as to make an age determination of any abrasive injury comprehensive knowledge of the timing of the repair process is needed. This further help to establish the causal relationship between the time of infliction to the time of examination, which is medicolegally significant.

The estimation of age of injury is particularly important with children who have experienced physical abuse and aids the determination of when the abuse took place and whether there were multiple episodes. ${ }^{3}$

A review of literature has highlighted the paucity of data, there are variations in the conclusion of the studies done in the recent past. Some studies have shown that the color change differs from the described in the standard literature. However no recent detailed Indian study is available on this aspect. Hence a study is required, at our set up to ascertain age of injury by comparing with the color changes with that of the time of infliction of injury as informed by the police/FIR/hospital records.
So the aim of this study was to estimate the age of abrasion by looking into the changes occurring due to healing of skin.

\section{Materials and Methods}

It is a descriptive, observational study. This study was carried out at Sri Aurobindo Medical College \& P.G. Institute, Indore on 100 individuals. Injured person brought to the emergency/ OPD/IPD /cases or for post mortem examination were selected, who are having abrasions on their body. Study was commenced after approval by Institutional Ethical Committee (IEC) of Sri Aurobindo Medical College \& P.G. Institute, Indore.

Patients were explained about procedure and purpose of the study. Informed consent was then sought and obtained in patients own language. Detailed history was taken about time of infliction of injuries and recorded as alleged by the victim/attendants and corroborated by the statements recorded by the investigating police officer. Treatment case sheets of patients were reviewed as and when required.

Injuries were examined including scaled photographs using colour scale (Table 1) and their time since infliction will be recorded and the documentation of injuries on the person will be noted on the prescribed proforma. Repeated subsequent examination of each case will be carried out at time of first inspection, then between $12-24$ hours, $2^{\text {nd }}$ day, 3 rd day, $4^{\text {th }}$ day, $5^{\text {th }}$ and continuing it on every day till their time of healing is reached to record various changes and conclusion will be drawn.

As healing of injury is a continuous process, various changes occurring during healing process is graded in present study as follows: 
Table 1: Healing of abrasion:

\begin{tabular}{|l|l|}
\hline Abrasion & Bright Red (Fig. 2) \\
\cline { 2 - 3 } & Formation of reddish scab started \\
\cline { 2 - 3 } & Scab formation is complete (Fig. 3) \\
\cline { 2 - 3 } & Scab turns brown \\
\cline { 2 - 3 } & Scab turns dark brown(Fig. 4) \\
\cline { 2 - 2 } & Scab turns black (Fig. 5) \\
\cline { 2 - 2 } & $\begin{array}{l}\text { Scab started falling from periphery } \\
\text { towards centre }\end{array}$ \\
\cline { 2 - 2 } & $\begin{array}{l}\text { Falling of scab is nearly complete (Fig. } \\
6)\end{array}$ \\
\cline { 2 - 2 } & Falling of scab is complete \\
\hline
\end{tabular}

\section{Inclusion Criteria:}

1. Injured patients attending the emergency/OPD/IPD/ cases for post mortem examination at Sri Aurobindo Medical College \& P.G. Institute.

2. Injuries those are in exposed area.

3. Subjects who are in between $18-60$ yrs.

4. Abrasions as a result of road traffic accident, assault, fall from height etc.

Exclusion Criteria:

1. Cases not consenting for the study.

2. Cases in which abrasions are adjoined/associated with deeper injuries like lacerated wound and fracture and are covered.

3. Cases with super-added infection.

4. Limitations:

5. Patients who are undiagnosed case of diabetes, bleeding disorders, connective tissue disorders, skin disorders, auto-immune disorders.

6. False interpretation due to wrong history given by victim / attendant.

7. Interpretation of colour of injuries in case of bruise varies from person to person due to colour of skin. In dark skinned individuals precise interpretation of colour of contusion is not possible.

8. Patients who died in between and cannot be followed due to other associated serious complications.

9. Analysis: Data is collected and tabulated using MS Excel 2010. It is analysed using SPSS (Licensed version). It is compared and discussed with results of studies available in literature.

\section{Results}

100 individuals of different age group (Table 2) were included in this study. Out of this there were 38 females and 62 males. All the above mentioned stages of abrasion healing were studied. $100 \%$ individual showed bright red abrasion for first $12 \mathrm{hrs}$ (Table 3). Reddish scab formation started in all the included individual within 12 to $24 \mathrm{hrs}$ (Table 3). Scab formation was completed within 12 to $48 \mathrm{hrs}$ in $7 \%$ individuals and within $24-48$ hrs in $93 \%$ individuals (Table 3 ). Scab turned brown within 24 to $48 \mathrm{hrs}$ in $54 \%$ individuals while in other $46 \%$ individuals it was seen on day 3 (Table 3). Healing reached another stage of scab turning dark brown on $3^{\text {rd }}$ and $4^{\text {th }}$ day in $41 \%$ individuals while it was seen completed on day 5 in $18 \%$ individual (Table 3 ). There were variations present in scab turning black among different individuals (Table 3). 3\% subjects showed this on day 3 while it was evident on $4^{\text {th }}$ day in $44 \%$ individuals. Variable results were seen in last two stages of abrasion wound healing (Table 3, Fig. 1).

Table 2: Distribution of patients according to age (Abrasion)

\begin{tabular}{|l|c|c|c|}
\hline S. No. & \multirow{2}{*}{ Age in years } & \multicolumn{2}{|c|}{$\begin{array}{c}\text { Total } \\
(\mathbf{n = 1 0 0})\end{array}$} \\
\cline { 3 - 4 } & & No. & Percentage \\
\hline 1. & $18-20$ & 20 & $20 \%$ \\
\hline 2. & $21-30$ & 30 & $30 \%$ \\
\hline 3. & $31-40$ & 25 & $25 \%$ \\
\hline 4. & $41-50$ & 13 & $13 \%$ \\
\hline 5. & $51-60$ & 12 & $12 \%$ \\
\hline
\end{tabular}

Table 3: Distribution of abrasion according to condition - Bright Red, formation of red scab\& scab formation complete

\begin{tabular}{|c|c|c|c|}
\hline \multirow[t]{2}{*}{ Condition } & \multirow[t]{2}{*}{ Time } & \multicolumn{2}{|c|}{$\begin{array}{c}\text { Total } \\
(\mathbf{N}=\mathbf{1 0 0})\end{array}$} \\
\hline & & No. & Percentage \\
\hline Bright red & $0-12$ hours & 100 & 100 \\
\hline $\begin{array}{l}\text { Formation of } \\
\text { reddish scab }\end{array}$ & $12-24$ hours & 100 & 100 \\
\hline \multirow{2}{*}{$\begin{array}{l}\text { Scab } \\
\text { formation } \\
\text { complete }\end{array}$} & 12-24 hours & 7 & 7 \\
\hline & 24-48 hors & 93 & 93 \\
\hline \multirow{2}{*}{$\begin{array}{l}\text { Scab turns } \\
\text { brown }\end{array}$} & 24-48 hours & 54 & 54 \\
\hline & Day 3 & 46 & 46 \\
\hline \multirow{3}{*}{$\begin{array}{l}\text { Scab turns } \\
\text { dark brown }\end{array}$} & Day 3 & 41 & 41 \\
\hline & Day 4 & 41 & 41 \\
\hline & Day 5 & 18 & 18 \\
\hline \multirow{5}{*}{$\begin{array}{l}\text { Scab turns } \\
\text { blacks }\end{array}$} & Day 3 & 3 & 3 \\
\hline & Day 4 & 44 & 44 \\
\hline & Day 5 & 25 & 25 \\
\hline & Day 6 & 19 & 19 \\
\hline & Day 7 & 9 & 9 \\
\hline \multirow{4}{*}{$\begin{array}{l}\text { Scab started } \\
\text { falling from } \\
\text { periphery } \\
\text { towards centre }\end{array}$} & Day 5 & 49 & 49 \\
\hline & Day 6 & 29 & 29 \\
\hline & Day 7 & 11 & 11 \\
\hline & Day 8 & 11 & 11 \\
\hline
\end{tabular}


Table 4: Abrasion

\begin{tabular}{|l|c|c|c|c|}
\hline \multicolumn{1}{|c|}{ Color change } & N.G. Rao & K. Vij $^{\mathbf{2}}$ & K.S.N Reddy $^{\mathbf{9}}$ & J.P Modi $^{\mathbf{1 0}}$ \\
\hline $\begin{array}{l}\text { Bright red lesion with oozing of } \\
\text { serum with blood }\end{array}$ & $\begin{array}{c}\text { Freshly } \\
\text { produced }\end{array}$ & Fresh & Fresh & Fresh \\
\hline $\begin{array}{l}\text { Blood \& lymph which dress up } \\
\text { \& forms, reddish scab }\end{array}$ & $12-24$ hrs & $12-24 \mathrm{hrs}$ & $12-24 \mathrm{hrs}$ & $\begin{array}{c}12-24 \\
\text { hours }\end{array}$ \\
\hline Scab turns reddish brown & - & $2-3$ days & $2-3$ days & $1-2$ day \\
\hline Scab turns dark brown & $2-3$ days & $4-7$ days & $4-7$ days & $3-5$ day \\
\hline Scab turns brownish black & - & - & $5-7$ days & - \\
\hline $\begin{array}{l}\text { Scab dries \& falls off leaving } \\
\text { depigmented area underneath }\end{array}$ & After 7 days & After 7 days & $7-10$ days & $5-7$ day \\
\hline
\end{tabular}

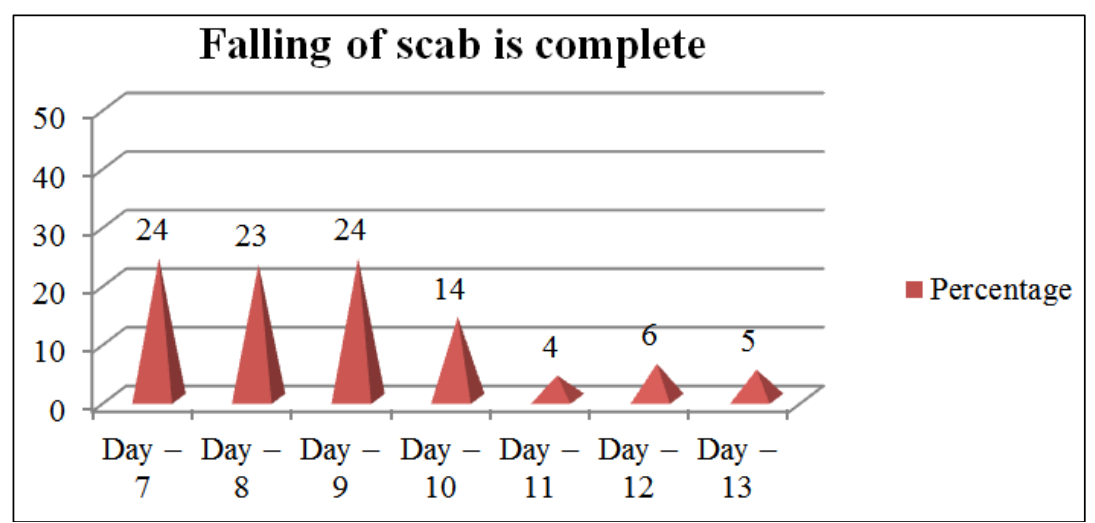

Fig. 1: Distribution of abrasion according to condition- Falling of scab is complete

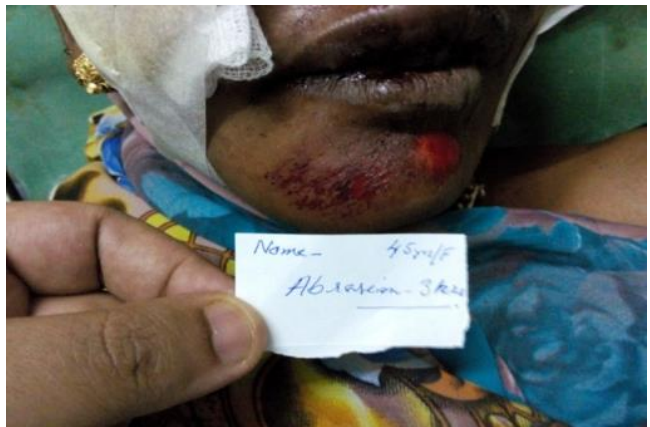

Fig. 2: Abrasion - bright red

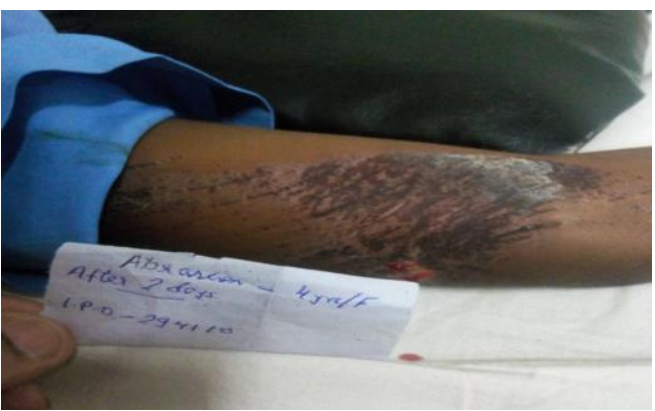

Fig. 3: Abrasion - Scab formation is complete

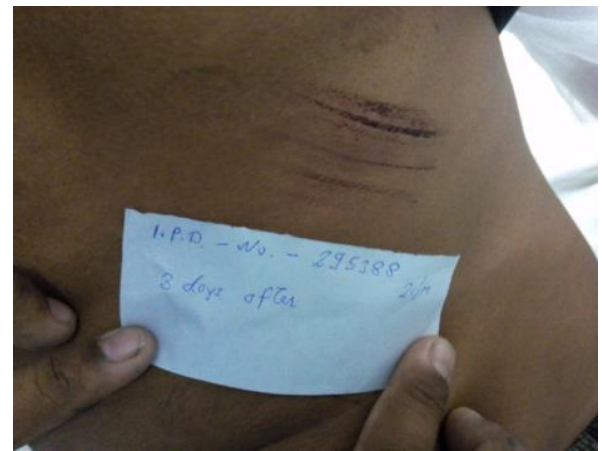

Fig. 4: Abrasion - Scab turns dark brown

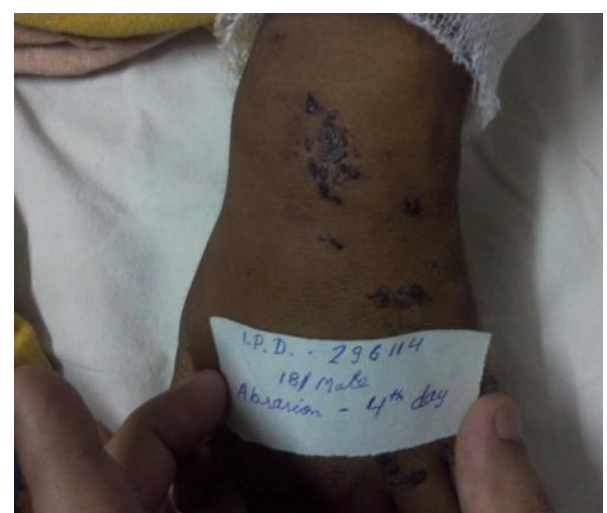

Fig. 5: Abrasion - Scab turns black 


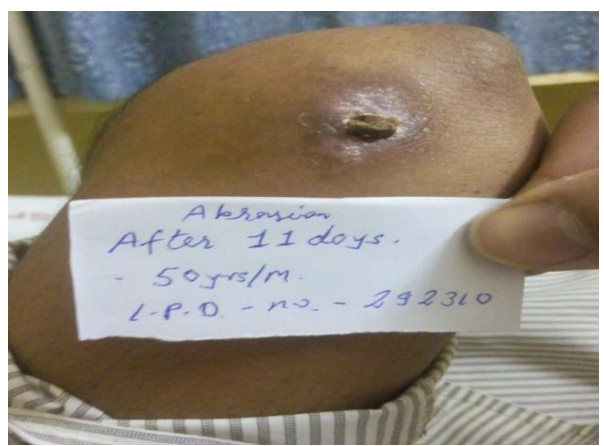

Fig. 6: Abrasion - Falling of scab

\section{Discussion}

Abrasion wounds occur when skin surface moves with pressure on object. Depending upon movement against the skin surface and pressure application, abrasion can be classified as linear abrasions, grazes, pressure abrasion and imprint abrasions. Scratches or the linear abrasions are caused by sharp and pointed objects passing across the skin, such as fingernails, thorn or pin. The surface layer of skin is collected in front of the object, which leaves a clean area at the start and tags at the end. Fingernail abrasions are seen in strangulation, sexual attack and child abuse. ${ }^{4}$ Graze abrasions are produced by the sliding movement of broad or wider surface against the skin. They are wider at the starting point and they get narrower at the end and shows uneven, longitudinal, parallel lines with epithelium heaped up at the ends indicating towards the direction of movement of the causative object of surface. Such grazed abrasions are called as brush burn. ${ }^{5}$ Pressure abrasions are caused by continuous pressure exerted by the force leaving the impression of the object on the area pressed. Pressure abrasion can show the pattern of the pressing object on the pressed area. Ligature mark of hanging and strangulation are the examples of pressure abrasion. ${ }^{6}$ Imprint abrasion are caused by impact with a rough object when the force is applied at or near a right angle to the skin surface and is slightly depressed below the surface. When a person is knocked down by a motor car and the pattern of the radiator grill may be seen on the skin which may contain road dirt, grease. Impact abrasions and pressure abrasions reproduced the pattern of the object causing it and are called patterned abrasions.

Abrasions heal rapidly without any scar formation unless they involve the dermis. Immediately after injury, serum and blood collects at the site. This transudate dries up to form reddish scab, it comprises of dried blood lymph and injured epithelial cells. Tenderness reduces and scab turns reddish brown. Scab maturation continues and starts falling off. Gradually scab shrinks and starts to shed off leaving behind depigmented area. ${ }^{7}$ Aging of abrasion can be recorded by observation of colour and condition of abrasion during process of healing. In older literature certain variations are seen in time duration of scab formation.
According to our experiences, certain inferences were variable as compared to published literature (Table 4). We did study on 100 individuals. Maximum cases $(30 \%)$ in the present study were observed in age group of 21-30 years. Likewise, males (62\%) were more commonly involved in the present study. Similar were findings were observed by Sandhu. S.S et al. ${ }^{8}$ Males and individuals in age group of 21-30 years are more affected by abrasions probably as they are more involved in outdoor activities and hence are more exposed to blunt trauma. In present study, bright red color of abrasion was observed from 0 hours (Time of infliction) to 12 hours in 100 cases (100\%). Findings of the study are similar also with observations of Indian authors. ${ }^{1,2,9,10}$ In the present study, formation of reddish scab started was observed in 100 cases (100\%) from 12 hours to 24 hours. These results were consistent to other similar studies been published. According to the study of $\mathrm{N} \mathrm{G} \mathrm{Rao}{ }^{1}$ and K S N Reddy ${ }^{9}$ complete scab formation was seen in 12-24 hrs but in our study $93 \%$ cases had scab formation in 24-48 hrs. Findings in terms of scab colour change were consistent with studies done by Indian authors. Complete scab shedding off was seen in day 7-10. Similar results were seen in studies of NG Rao and K Vij. ${ }^{2}$

\section{Medico Legal Consideration}

1. Such injuries should be carefully examined as they may be the only external visible signs of severe or even fatal internal injury.

2. Their sites and distributions over the body may yield some clue towards the nature of crime. They exhibit the pattern thereby providing information regarding nature of force.

3. Direction of application of force may be inferred from the collected epithelial tags at distal end of the abraded area.

4. Multiple stages of healing are helpful to determine approximated time of injury infliction.

5. Presence of some material like mud, grit, coal-dust, cement, sand, lime-dust, pebbles or any vegetation, etc. In and around the abraded area, will suggested the mature of the surface or agent responsible for its causation.

\section{Conclusion}

Following this study we came to the conclusion that minor or major abrasive injuries hold a significant role in drawing the inference in medico legal cases. Injured body should be examined very carefully. Colour changes following abrasion injuries requires a keen observation. Healing of injuries is multifactorial. Therefore other investigatory clues should always be considered while making a decision. 


\section{References}

1. Rao NG. Text book of forensic medicine and toxicology. $2^{\text {nd }}$ ed. New Delhi: Jaypee Publication; 2010.

2. Vij K. Textbook of Forensic Medicine and Toxicology Principles and Practice. $3^{\text {rd }}$ ed. New Delhi. Reed Elsevier India Pvt Ltd.;2005.

3. Pilling ML, Vanezis P, Perrett D, Johnston A. Visual assessment of the timing of bruising by forensic experts. $J$ Forensic Leg Med. 2009;17:143-9.

4. Biswas GB. Review of forensic medicine and toxicology. $1^{\text {st }}$ ed. New Delhi: Jaypee publisher; 2010.

5. Bardale R. Principles of forensic medicine and toxicology. $1^{\text {st }}$ ed. New Delhi: Jaypee publishers; 2011.

6. Subrahmanyam BV. Forensic medicine, Toxicology and medical jurisprudence. $1^{\text {st }}$ ed. New Delhi: Modern publishers; 2004.

7. Cotran RS, Kumar V, Collins T. Tissue Repair: Cellular Growth, Fibrosis, and Wound Healing. Robbins Pathological basis of diseases. $7^{\text {th }}$ ed: Noida: Thomson Press (I) Ltd; 2000.

8. Sandhu SS, Gorea RK, Gargi J, Garg A. Age estimation of injury from abrasion- A clinical study from north India. Journal of Punjab academy of Forensic Medicine \& Toxicology. 2009;9:pp 76-80.

9. Reddy KSN. The essentials of forensic medicine and toxicology. $33^{\text {rd }}$ ed. Hyderabad. Jaypee publishers; 2014

10. Modi JP. Modi's Medical Jurisprudence \& Toxicology. $22^{\text {nd }}$ ed. New Delhi: Tripathi Publication; 2002. 